\title{
Disparate Antibiotic Resistance Gene Quantities Revealed across 4 Major Cities in California: A Survey in Drinking Water, Air, and Soil at 24 Public Parks
}

Cristina M. Echeverria-Palencia, ${ }^{\dagger}$ Vanessa Thulsiraj, ${ }^{\dagger, \ddagger}$ Nghi Tran, ${ }^{\S}$ Cody A. Ericksen, ${ }^{\S}$ Isabel Melendez, $^{\S}$ Michael G. Sanchez, ${ }^{\S}$ Devin Walpert, ${ }^{\S}$ Tony Yuan, ${ }^{\S}$ Elizabeth Ficara, ${ }^{\S}$ Niru Senthilkumar, ${ }^{\dagger}$ Fangfang Sun, ${ }^{\dagger}$ Renjie Li, ${ }^{\dagger}$ Marisol Hernandez-Cira, ${ }^{\dagger}$ Demi Gamboa, ${ }^{\dagger}$ Heather Haro, ${ }^{\dagger}$ Suzanne E. Paulson, ${ }^{\S}$ Yifang Zhu, ${ }^{\S \odot}$ and Jennifer A. Jay ${ }^{*}, \S_{(}$

${ }^{\dagger}$ Civil and Environmental Engineering Department, University of California at Los Angeles, 420 Westwood Plaza, Los Angeles, California 90095, United States

${ }^{\ddagger}$ Biology Department, Mount Saint Mary’s University, 12001 Chalon Road, Los Angeles, California 90049, United States

${ }^{\S}$ Institute of the Environment and Sustainability, University of California at Los Angeles, LaKretz Building, Los Angeles, California 90095, United States

\section{Supporting Information}

ABSTRACT: Widespread prevalence of multidrug and pandrug-resistant bacteria has prompted substantial concern over the global dissemination of antibiotic resistance genes (ARGs). Environmental compartments can behave as genetic reservoirs and hotspots, wherein resistance genes can accumulate and be laterally transferred to clinically relevant pathogens. In this work, we explore the ARG copy quantities in three environmental media distributed across four cities in California and demonstrate that there exist city-to-city disparities in soil and drinking water ARGs. Statistically significant differences in ARGs were identified in soil, where differences in $b l a_{\mathrm{SHV}}$ gene copies were the most striking; the highest copy numbers were observed in Bakersfield $(6.0 \times$ $10^{-2}$ copies/16S-rRNA gene copies and $2.6 \times 10^{6}$ copies/g of soil $)$, followed by San Diego $\left(1.8 \times 10^{-3}\right.$ copies $/ 16 \mathrm{~S}$-rRNA gene copies and $3.0 \times 10^{4}$ copies/g of soil $)$, Fresno $\left(1.8 \times 10^{-5}\right.$ copies/16S-rRNA gene copies and $8.5 \times 10^{2}$ copies/g of soil $)$, and Los Angeles $\left(5.8 \times 10^{-6}\right.$ copies/16S-rRNA gene copies and $5.6 \times 10^{2}$ copies/g of soil $)$. In addition, ARG copy numbers in the air, water, and soil of each city are contextualized in relation to globally reported quantities and illustrate that individual genes are not necessarily predictors for the environmental resistome as a whole.

\section{INTRODUCTION}

A sustained rise in antimicrobial resistance is predicted to lead to 10 million deaths per year by 2050, with the current resistance accounting for a minimum of 700000 lives lost per year. $^{1,2}$ Concurrently, recent cases of multi- and pandrugresistant bacteria have raised questions about the future of the current last line of defense antibiotics and, by extension, the future treatability of common bacterial infections. ${ }^{3,4}$

Emergence of antibiotic-resistant pathogenic bacteria has directed substantial attention toward antibiotic resistance genes (ARGs), which confer resistance and can be transferred among bacteria through horizontal gene transfer (HGT). ${ }^{5}$ Additionally, environmental co-selective pressures can drive antibioticresistant strain development, promote persistence of ARGs, and result in ARG abundance in the absence of antibiotic selective pressure. ${ }^{6-8}$ Considered as environmental contaminants of emerging concern, ARG abundance in environmental compartments warrants increased documentation. ${ }^{9-12}$ Indeed, recent work has pointed to the importance of environmental routes for disease transmission, ${ }^{13-15}$ with several examples of ARGs in clinical isolates believed to be derived from environmental bacteria. ${ }^{15}$

Possible ARG sources to the environment, including wastewater treatment plants, ${ }^{16-18}$ confined animal feeding operations, ${ }^{19,20}$ manure-fertilized fields, ${ }^{21}$ and medical waste streams, ${ }^{22,23}$ comprise an intricate system that consistently inputs ARGs into the environment. However, although these sources continue to be explored, the current volume of studies on the extent of dissemination of ARGs in environmental compartments is lacking.

Received: February 2, 2017

Accepted: April 17, 2017

Published: May 24, 2017 
Table 1. P-Values from Welch's T-Test Comparisons between Soils in California Cities

\begin{tabular}{l|l|l|l|l}
\cline { 1 - 1 } Soil: $b l a_{\text {SHV }}$ & $\begin{array}{l}\text { LA } \\
\text { (copies/g) }\end{array}$ & $\begin{array}{l}\text { SD } \\
\text { (copies/g) }\end{array}$ & $\begin{array}{l}\text { Bks } \\
\text { (copies/g) }\end{array}$ & $\begin{array}{l}\text { F } \\
\text { (copies/g) }\end{array}$ \\
\cline { 1 - 1 } Los Angeles & & 0.024 & 0.003 & 0.340 \\
\hline San Diego & & & 0.003 & 0.025 \\
\hline Bakersfield & & & & 0.003 \\
\hline Fresno & & & &
\end{tabular}

\begin{tabular}{l|l|l|l|l} 
Soil: $b l a_{\text {SHV }}$ & $\begin{array}{l}\text { LA } \\
\text { (copies } \\
\text { (16S) }\end{array}$ & $\begin{array}{l}\text { SD } \\
\text { (copies /16S) }\end{array}$ & $\begin{array}{l}\text { Bks } \\
\text { (copies /16S) }\end{array}$ & $\begin{array}{l}\text { F } \\
\text { (copies /16S) }\end{array}$ \\
\cline { 1 - 1 } Los Angeles & & 0.017 & 0.003 & 0.055 \\
\hline San Diego & & & 0.003 & 0.017 \\
\hline Bakersfield & & & & 0.003 \\
\hline Fresno & & & &
\end{tabular}

\begin{tabular}{|l|l|l|l|l} 
Soil: sul1 & $\begin{array}{l}\text { LA } \\
\text { (copies/g) }\end{array}$ & $\begin{array}{l}\text { SD } \\
\text { (copies/g) }\end{array}$ & $\begin{array}{l}\text { Bks } \\
\text { (copies/g) }\end{array}$ & $\begin{array}{l}\text { F } \\
\text { (copies/g) }\end{array}$ \\
\cline { 1 - 1 } Los Angeles & & 0.321 & 0.313 & 0.309 \\
\hline San Diego & & & 0.186 & 0.063 \\
\hline Bakersfield & & & & 0.115 \\
\hline Fresno & & & &
\end{tabular}

\begin{tabular}{|l|l|l|l|l}
\multirow{2}{*}{ Soil: sul1 } & $\begin{array}{l}\text { LA } \\
\text { (copies } \\
\text { (16S) }\end{array}$ & $\begin{array}{l}\text { SD } \\
\text { (copies /16S) }\end{array}$ & $\begin{array}{l}\text { Bks } \\
\text { (copies /16S) }\end{array}$ & $\begin{array}{l}\text { F } \\
\text { (copies /16S) }\end{array}$ \\
\cline { 1 - 1 } Los Angeles & & 0.369 & 0.284 & 0.287 \\
\hline San Diego & & & 0.05 & 0.06 \\
\hline Bakersfield & & & & 0.85 \\
\hline Fresno & & & &
\end{tabular}
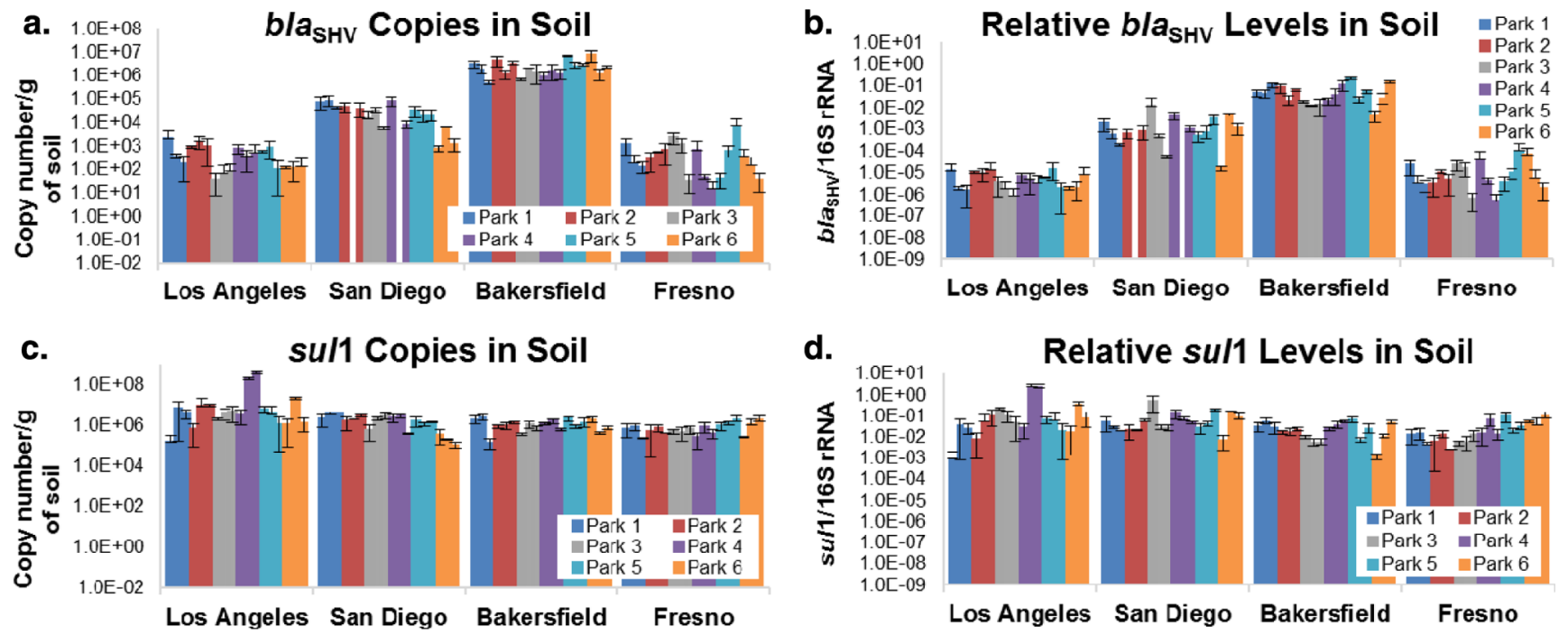

Figure 1. $b a_{\mathrm{SHV}}$ and sul $\mathrm{ARG}$ quantities in California soils. Soil ARG gene copy numbers across 24 parks in 4 California cities. Error bars denote intrapark variability when averaged over three sampling triplicates. (a) bla $a_{\mathrm{SHV}}$ copy numbers normalized to per gram of soil, (b) bla $a_{\mathrm{SHV}}$ copies per 16S-rRNA gene copies, (c) sul1 copy numbers normalized to per gram of soil, and (d) sul1 copies per 16S-rRNA gene copies.

Background ARG quantities in soils have been confirmed as altered and increasing due to anthropogenic antibiotic use, ${ }^{19,21,24}$ but there is little research quantitatively reporting them. Instead, data often focus on fold increases due to a particular human activity, such as manure application ${ }^{21,25-27}$ or reclaimed water use, ${ }^{28-30}$ making site-to-site comparisons difficult. Studies on waterborne ARG quantities are more extensively available and have included surface, ${ }^{31,32}$ ground $^{20}$ and coastal waters, $^{33}$ drinking water effluent, ${ }^{34,35}$ and tap water, $^{36,37}$ but the large majority of investigation has not involved water systems that directly interact with general populations, leaving open questions concerning ARG exposure. Air is by far the least studied environmental compartment with the majority of research addressing only antibiotic-resistant bacteria (ARB).$^{38-40}$ Some quantitative ARG values have been reported; however, these are typically in response to and downwind of a suspected source, rarely concerning ARGs affecting populations outside of immediate feedlot vicinities. $^{41-43}$
When available, studies reporting ARG quantities in environmental compartments are often difficult or impossible to compare, with researchers reporting results in different units, as well as reporting different genes. Moreover, a broad resistance profile of a particular site is rare, with many studies focused solely on a single environmental compartment. Several public databases and global surveillance projects exist; however, these focus on clinical isolates, rather than ARGs in the environment.

In this study, ARGs were assessed in 26 public parks across 4 major California cities and three environmental media: soil, drinking water, and air. It was hypothesized that unique ARG profiles exist across medium, genes and location, such that when comparing cities within California, city-to-city differences would be identified. Air, water, and soil from each site was analyzed for two ARGs, sul1 and bla $a_{\mathrm{SHV}}$, as well as the bacterial 16S-rRNA gene. Additionally, all soil samples were analyzed for the erm $\mathrm{F}$ and erm $\mathrm{B}$ genes. sull gene was selected for inclusion in this study due to its proposed use as an urbanization marker, ${ }^{44}$ its propensity for persisting in the environment, ${ }^{45,46}$ 

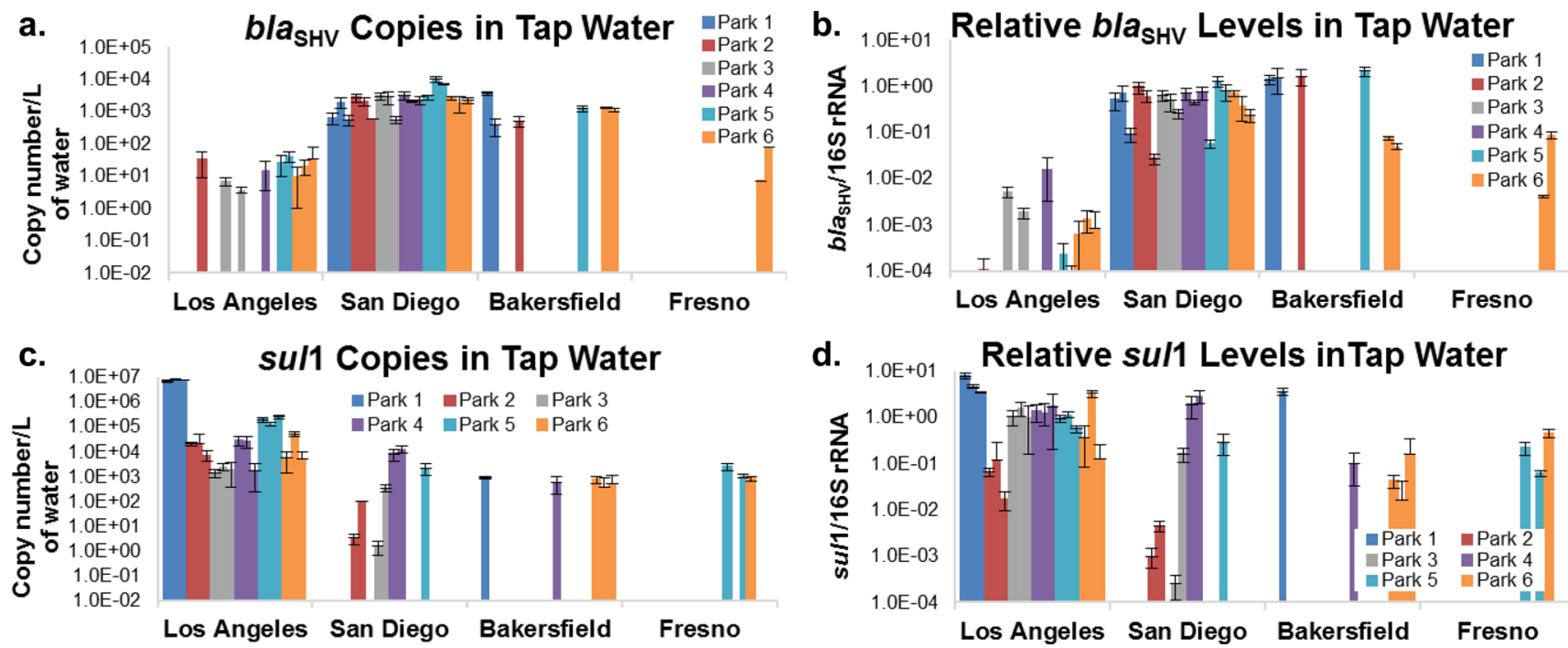

Figure 2. $b l a_{\mathrm{SHV}}$ and sul1 ARG quantities in California tap water. Tap water ARG gene copy numbers across 24 parks in 4 California cities. Error bars denote intrapark variability when averaged over three sampling triplicates. (a) bla $a_{\mathrm{SHV}}$ copy numbers normalized to per liter of water, (b) bla ${ }_{\mathrm{SHV}}$ copies per 16S-rRNA gene copies, (c) sul1 copy numbers normalized to per liter of water, and (d) sul1 copies per 16S-rRNA gene copies.

Table 2. P-Values from Welch's T-Test Comparisons between Tap Water in California Cities

\begin{tabular}{|l|l|l|l|l}
$\begin{array}{l}\text { Tap Water: } \\
\text { bla }_{\text {SHV }}\end{array}$ & $\begin{array}{l}\text { LA } \\
\text { (copies/L) }\end{array}$ & $\begin{array}{l}\text { SD } \\
\text { (copies/L) }\end{array}$ & $\begin{array}{l}\text { Bks } \\
\text { (copies/L) }\end{array}$ & $\begin{array}{l}\text { F } \\
\text { (copies/L) }\end{array}$ \\
\hline Los Angeles & & 0.019 & 0.096 & 0.370 \\
\hline San Diego & & & 0.035 & 0.019 \\
\hline Bakersfield & & & & 0.093 \\
\hline Fresno & & & &
\end{tabular}

\begin{tabular}{l|l|l|l|l}
$\begin{array}{l}\text { Tap Water: } \\
\text { bla }\end{array}$ & $\begin{array}{l}\text { LA } \\
\text { (copies /16S) }\end{array}$ & \begin{tabular}{l} 
SD \\
(copies /16S) \\
\cline { 1 - 1 } Los Angeles
\end{tabular} & $\begin{array}{l}\text { Bks } \\
\text { (copies /16S) }\end{array}$ & $\begin{array}{l}\text { F } \\
\text { (copies/16S) }\end{array}$ \\
\cline { 1 - 1 } San Diego & & $8.74 \mathrm{E}-05$ & 0.083 & 0.288 \\
\hline Bakersfield & & & 0.444 & $8.56 \mathrm{E}-05$ \\
\hline Fresno & & & & 0.086 \\
\hline
\end{tabular}

\begin{tabular}{|l|l|l|l|l} 
Tap Water: sul1 & $\begin{array}{l}\text { LA } \\
\text { (copies/L) }\end{array}$ & $\begin{array}{l}\text { SD } \\
\text { (copies/L) }\end{array}$ & $\begin{array}{l}\text { Bks } \\
\text { (copies/L) }\end{array}$ & $\begin{array}{l}\text { F } \\
\text { (copies/L) }\end{array}$ \\
\cline { 1 - 1 } Los Angeles & & 0.347 & 0.346 & 0.346 \\
\hline San Diego & & & 0.363 & 0.396 \\
\hline Bakersfield & & & & 0.739 \\
\hline Fresno & & & &
\end{tabular}

\begin{tabular}{l|l|l|l|l} 
Tap Water: sul1 & \multirow{2}{*}{$\begin{array}{l}\text { LA } \\
\text { (copies /16S) }\end{array}$} & $\begin{array}{l}\text { SD } \\
\text { (copies /16S) }\end{array}$ & $\begin{array}{l}\text { Bks } \\
\text { (copies /16S) }\end{array}$ & $\begin{array}{l}\text { F } \\
\text { (copies /16S) }\end{array}$ \\
\cline { 1 - 1 } Los Angeles & & 0.126 & 0.111 & 0.078 \\
\hline San Diego & & & 0.869 & 0.382 \\
\hline Bakersfield & & & & 0.409 \\
\hline Fresno & & & &
\end{tabular}

and a high degree of previously recorded data, which allows for ARG quantity contextualization. The $b l a_{\mathrm{SHV}}$ gene was included in this study due to its close relationship to the genes suggested for environmental monitoring. ${ }^{47}$ Additionally, along with erm genes, $b l a_{\mathrm{SHV}}$ gene copy quantities had been shown to be increasing in soils. ${ }^{24} \mathrm{ermB}$ and erm $\mathrm{F}$ have both been proposed as indicators for assessing the antibiotic resistance status of a particular environment. ${ }^{47}$ Together, ermB and erm $\mathrm{F}$ can shed light on possible differences in genes that are closely related and operate via similar resistance mechanisms.

Through this work, we sought to provide a more comprehensive approach to documenting ARG exposure across a given region by introducing a study design that has not been utilized in conjunction with ARG monitoring. Additionally, this study is to our knowledge, the first to contextualize reported ARG quantities in relation to those reported globally.

\section{RESULTS}

$b l a_{\mathrm{SHV}}$. Gene copies of $b l a_{\mathrm{SHV}}$, with gene copies defined as the quantity of the target gene present in sample as determined via $\mathrm{qPCR}$, were regularly detected in all soil samples. For $b l a_{\mathrm{SHV}}$ gene copy numbers measured per gram of soil, all city-to-city comparisons, with the exception of the Los Angeles-Fresno comparison, revealed statistically significant differences (Welch's $t$-test $p<0.05$, comparing two cities at a time each with $n=24$ ) (Table 1 ), with ARG copy numbers highest in Bakersfield $\left(5.1 \times 10^{5}\right.$ to $6.9 \times 10^{6}$ copies $\left./ \mathrm{g}\right)$ followed by San Diego $\left(7.7 \times 10^{2}\right.$ to $9.0 \times 10^{4}$ copies $/ g$ when detected $)$ and tailed by both Los Angeles and Fresno $\left(3.5 \times 10^{1}\right.$ to $2.1 \times 10^{3}$ and $1.5 \times 10^{1}$ to $6.7 \times 10^{3}$ copies $/ g$ respectively), as summarized in Figure 1. When normalized by $16 \mathrm{~S}$-rRNA gene copies, city-to-city differences persisted (Table 1 ), with all relationships now found to statistically differ $(p<0.1)$. City quantities for $b l a_{\mathrm{SHV}}$ gene copies from highest to lowest were: Bakersfield $\left(1.9 \times 10^{-2}\right.$ to $2.2 \times 10^{-1}$ copies/16S-rRNA gene copies), San Diego $\left(1.5 \times 10^{-5}\right.$ to $1.2 \times 10^{-2}$ copies/16S-rRNA gene copies $)$, Fresno $\left(5.1 \times 10^{-7}\right.$ to $6.5 \times 10^{-5}$ copies $/ 16 \mathrm{~S}$ rRNA gene copies), and Los Angeles $\left(8.2 \times 10^{-7}\right.$ to $1.6 \times 10^{-5}$ copies/16S-rRNA gene copies), as summarized in Figure 1.

Detection of $b a_{\mathrm{SHV}}$ fluctuated in drinking water samples collected from Los Angeles, Bakersfield, and Fresno. In contrast, $b l a_{\mathrm{SHV}}$ was detected in all San Diego drinking water 

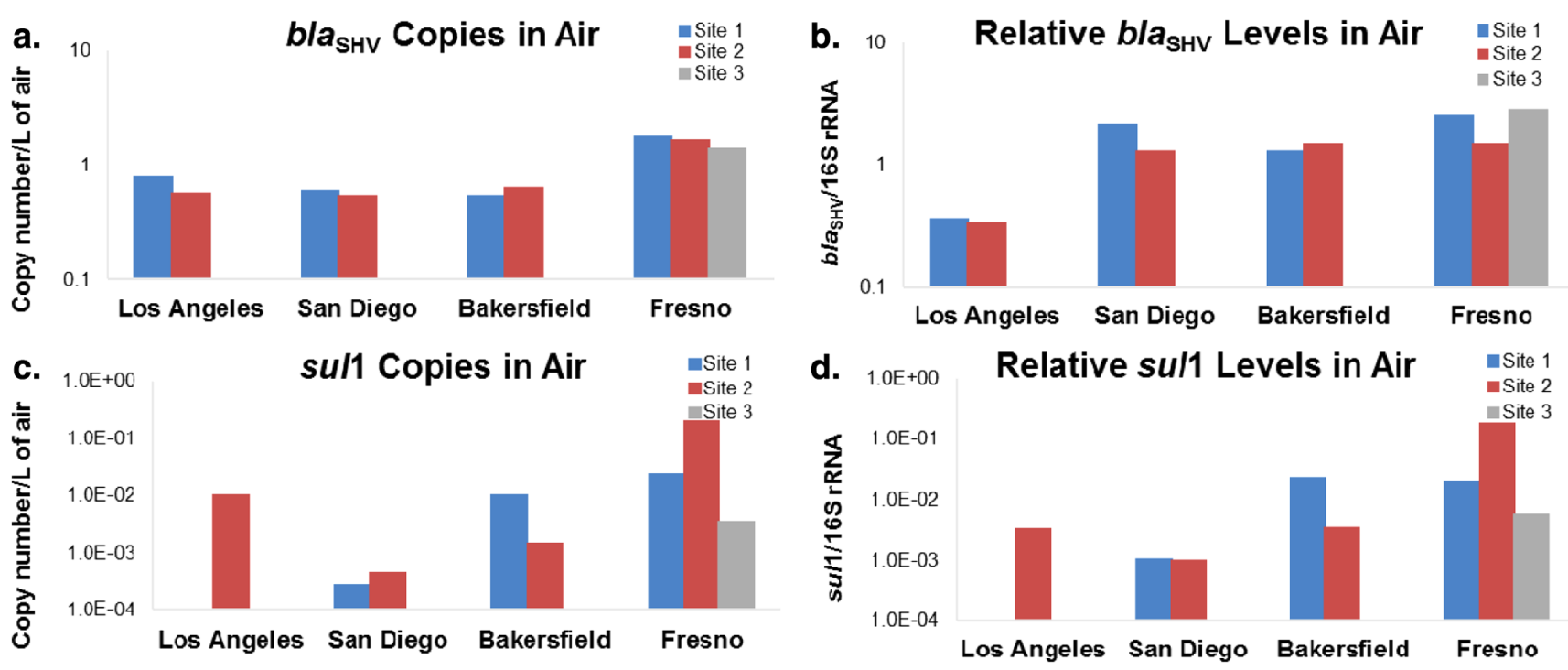

Figure 3. $b l a_{\mathrm{SHV}}$ and sul1 ARG quantities in California air. ARG gene copy numbers in air across four California cities: (a) bla $a_{\mathrm{SHV}}$ copy numbers normalized to per liter of air, (b) bla $a_{\mathrm{SHV}}$ copies per 16S-rRNA gene copies, (c) sull copy numbers normalized to per liter of air, and (d) sul1 copies per 16S-rRNA gene copies.

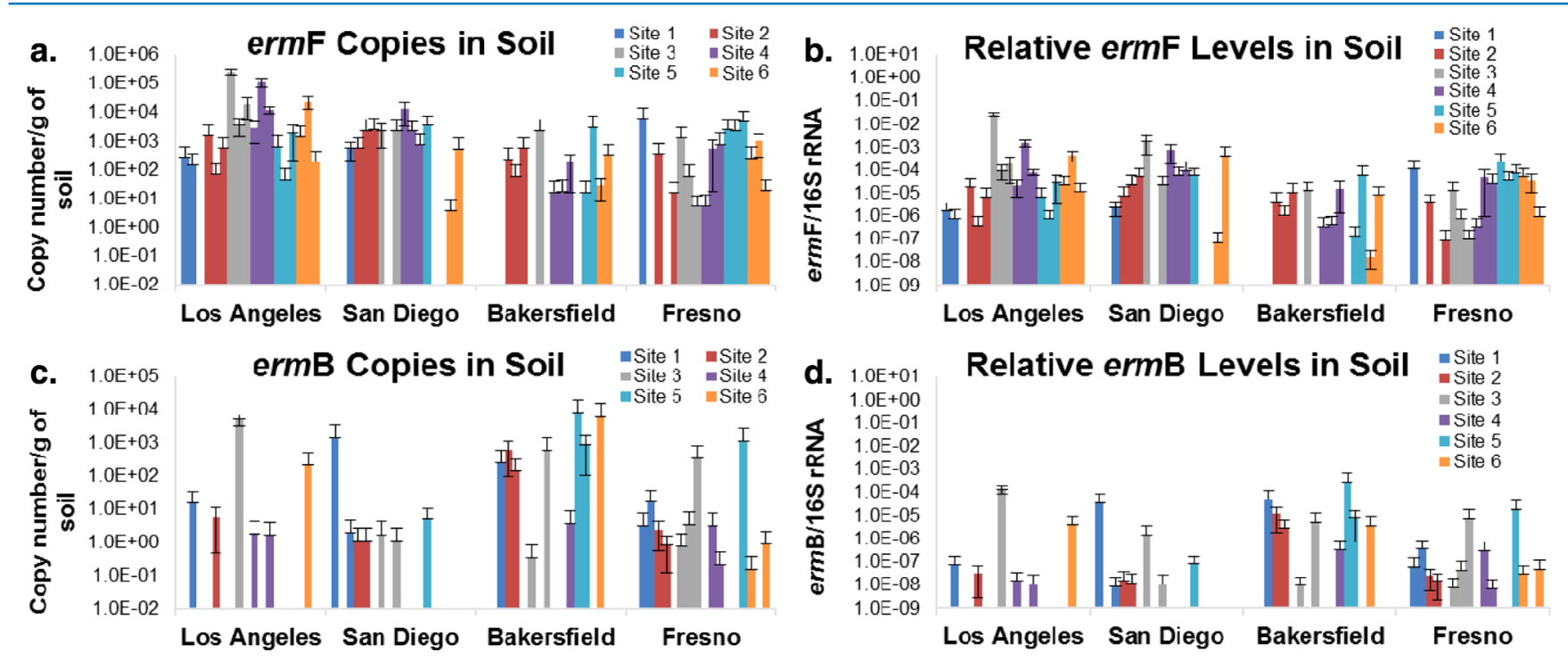

Figure 4. erm $\mathrm{F}$ and ermB ARG quantities in California soils. Soil ARG gene copy numbers across 24 parks in 4 California cities. Error bars denote intrapark variability when averaged over three sampling triplicates. (a) erm F copy numbers normalized to per gram of soil, (b) erm F copies per 16SrRNA gene copies, (c) ermB copy numbers normalized to per gram of soil, and (d) ermB copies per 16S-rRNA gene copies.

samples, as shown in Figure 2 (gene copy numbers ranged from $5.5 \times 10^{2}$ to $10.0 \times 10^{3}$ copies/L). Gene copy numbers normalized to per liter of drinking water were statistically different when comparing each city $(p<0.1)$, with the exception of an LA-Fresno comparison (Table 2). Overall, the ranking of gene copy number from highest to lowest was found to be: San Diego, Bakersfield, and equivalent lower relative ranking for Los Angeles and Fresno. When gene copy numbers were compared per 16S-rRNA gene copy number (Figure 2), all city differences were statistically significant $(p<0.1)$, with the exception of the LA versus Fresno and San Diego versus Bakersfield comparisons (Table 2). When viewed in relation to 16S-rRNA gene, two tiers were seen, with San Diego and Bakersfield both showing higher gene copy numbers $(2.7 \times$ $10^{-2}$ to 1.3 and $5.0 \times 10^{-2}$ to 2.1 copies/16S-rRNA gene copies respectively) than those of Los Angeles and Fresno $\left(9.4 \times 10^{-5}\right.$ to $5.1 \times 10^{-3}$ and $4.0 \times 10^{-3}$ to $8.6 \times 10^{-2}$ copies/16S-rRNA gene copies, respectively).

Because of sampling constraints, air was sampled at only two sites per city, with each site sampled in replicates of three to five. The exception to this was Fresno, where three sites were sampled. $b l_{\mathrm{SHV}}$ copy numbers per liter of air sampled revealed higher $b l a_{\mathrm{SHV}}$ gene copy numbers in Fresno (0.19-600 copies/ $\mathrm{m}^{3}$ ), with the gene copy numbers in Bakersfield, Los Angeles, and San Diego all found to be lower than the Fresno gene copy numbers by approximately $50 \%$ but comparable to each other (Figure 3 ). When analyzed per 16S-rRNA gene copy number, Los Angeles gene copy numbers were the lowest $\left(3.8 \times 10^{-4}\right.$ to $9.3 \times 10^{-3}$ copies/16S-rRNA gene copies), with significant overlaps among the Fresno, Bakersfield, and San Diego sites (Figure 3).

sul1. sul1 was consistently detected in soil across all parks and cities studied, with some variability observed to occur 
within any given park. City-to-city comparisons for sull gene copy numbers were found to be statistically different when comparing San Diego parks to those in Fresno (Table 1), with higher sull gene copy numbers measured in San Diego $(p=$ 0.06 ). When normalized by $16 \mathrm{~S}-\mathrm{rRNA}$ gene copy number, San Diego was found to have a higher gene presence than both Fresno and Bakersfield $(p<0.06)$, with similar gene copy quantities observed in Fresno and Bakersfield (Table 1). Los Angeles exhibited the most park-to-park variability (ranging 1.5 $\times 10^{5}$ to $4.0 \times 10^{8}$ copies/g and $9.0 \times 10^{-4}$ to 2.7 copies/16SrRNA gene copies), and ARG quantities did not prove to be significantly different from any of the other three cities, regardless of the normalization approach. sull values in soil were found to vary from $1.1 \times 10^{5}$ to $2.2 \times 10^{7}$ copies/g to 9.0 $\times 10^{-4}$ to $5.1 \times 10^{-1}$ copies/16S-rRNA gene copies, with two LA park values yielding particularly high values of $2.0 \times 10^{8}$ and $4.0 \times 10^{8}$ copies/g, and 2.6 and 2.7 copies/16S-rRNA gene copies (Figure 1).

The presence of sull per liter of water sampled was highly variable in San Diego (detected in 30\% samples), Bakersfield (detected in $21 \%$ of samples), and Fresno (detected in $13 \%$ samples), with Fresno having the lowest frequency of gene detection. In contrast, sul1 was detected in $100 \%(n=18)$ of Los Angeles drinking water samples. Absolute gene copy numbers of sul1 in San Diego, Bakersfield, and Fresno proved too variable to result in statistically significant city-to-city differences when compared to those of Los Angeles and to each other, as shown in Figure 2 and Table 2. When analyzing gene copies per copies of 16S-rRNA gene (Figure 2), only the LAFresno comparison exhibited a statistically significant city difference, with higher gene copy numbers observed in Los Angeles than those in Fresno $(p=0.08)$.

sul1 gene copy numbers in air were found to vary widely within individual cities with Fresno air measurements ranging from $1.5 \times 10^{1}$ to $5.3 \times 10^{3}$ copies $/ \mathrm{m}^{3}$, Bakersfield ranging from $1.4 \times 10^{2}$ to $7.2 \times 10^{2}$ copies $/ \mathrm{m}^{3}$, Los Angeles ranging from $1.6 \times 10^{1}$ to $1.6 \times 10^{2}$ copies $/ \mathrm{m}^{3}$, and San Diego ranging from $1.7 \times 10^{-2}$ to 2 copies $/ \mathrm{m}^{3}$. Absolute copy numbers per liter of air indicate a higher incidence of sull gene found in Fresno site 2 when compared to that found in the other three cities (Figure 3). After normalizing by 16S-rRNA gene copy number, Fresno site 2 gene copy numbers remained highest, followed by Bakersfield site 1 as a distant second (Figure 3).

ermF and ermB. Gene copy measurements for both erm $\mathrm{F}$ and erm $\mathrm{B}$ were obtained for soil samples, with both genes greatly fluctuating when detectable (Figure 4); ermF fluctuated between $3.9 \times 10^{0}$ and $2.6 \times 10^{5}$ copies/g and between $1.7 \times$ $10^{-8}$ copies/16S-rRNA gene and $2.7 \times 10^{-2}$ copies/16S-rRNA gene, whereas ermB fluctuated from $1.1 \times 10^{0}$ and $8.4 \times 10^{3}$ copies/g, and between $7.0 \times 10^{-9}$ copies/16S-rRNA gene and $2.7 \times 10^{-4}$ copies/16S-rRNA gene (Figure 4). In general, the erm $\mathrm{F}$ gene had a higher frequency of detection than that of ermB. ermF was consistently identified in Los Angeles park soils, with only one triplicate from site 1 failing to amplify via qPCR. All other cities contained at least one park with confirmed ARG readings obtained for only one out of three park samples. Overall, ermF detection frequency decreased in the order: Los Angeles, Fresno, San Diego, and finally Bakersfield. erm $\mathrm{B}$ was identified much less frequently, with the frequency of detection decreasing in the order: Fresno, Bakersfield, San Diego, and finally Los Angeles. No statistically different city-to-city relationships could be determined for either gene, regardless of the normalization technique. These results place erm $\mathrm{F}$ as per the above reported values and erm $\mathrm{B}$ as well below those currently shown in the literature.

California ARG Quantities in Global Context. Previous reports of sul1 per 16S-rRNA gene copies in archived soils, lake, and river sediments and environmental soil prior to manure or wastewater application allow this study to place average California soil quantities as generally above those currently documented in Germany, ${ }^{21}$ along the Poudre River in Colorado, ${ }^{31}$ and in a cornfield in Virginia. ${ }^{26}$ However, the range of values seen in this study is wide enough to be inclusive of many values reported in the aforementioned studies. The highest values previously published are identified as those in sediment from Lake Geneva, Switzerland (approx. up to 0.08 copies/16S-rRNA gene copies). ${ }^{48}$ The higher spectrum of values reported from the Lake Geneva site are found to be comparable to the quantities found in this study, although readings for San Diego and Los Angeles exceed the largest reported lake sediment values at several sampling sites. To our knowledge, these values place California sull gene copy numbers in soil above or comparable to the highest reported values. Absolute copy number was found to rarely be reported for sul1 in the soil compartment, with absolute values identified having also been reported as per 16S-rRNA gene copies. ${ }^{28}$

Gene copy numbers of sul1 normalized to per 16S-rRNA gene copies in aquatic environmental compartments have been documented in rivers, seas, lakes, bays, reservoirs, reclaimed water, and to a scarce extent, in drinking water. Placed within the context of these studies, it can be determined that drinking water ARG gene copy numbers observed in the California cities studied are generally higher than those recorded in lakes, rivers, and bays in locations ranging from Manila ${ }^{49}$ to $\mathrm{China}^{33}$ and Colorado $^{31}$ among others. Water bodies similar in order of magnitude to cities in California have been recorded in an urban and industrial river, ${ }^{50}$ sites along the Baltic Sea, ${ }^{51}$ Swiss lakes, ${ }^{52}$ and in drinking water treated from Lake Taihu, China. ${ }^{53}$ However, nearly all drinking water samples obtained from Los Angeles, CA, exceed these reported values by nearly an order of magnitude.

Relative to reporting for sull, information on $b l a_{\mathrm{SHV}}$ is infrequent, making global contextualization difficult. $b l a_{\mathrm{SHV}}$ per 16S-rRNA gene copy numbers have been reported in sediments in Cuba as well as in archived Scottish soils. ${ }^{7,54}$ ARG quantities in Cuban sediment were found to generally be comparable to soil values obtained for Fresno and Los Angeles, with Scottish soil values falling above those in Fresno and Los Angeles but below those in Bakersfield and San Diego. Absolute bla $a_{\mathrm{SHV}}$ values were only found reported once in Cuban sediments, with values found to be comparable to San Diego.

Although there exists scarce reporting of the $b l a_{\mathrm{SHV}}$ gene copy numbers in water bodies, this study is able to place $b l a_{\mathrm{SHV}}$ drinking water quantities in Los Angeles and Fresno as below those reported in the Baltic Sea ${ }^{51}$ and along the Almendares River in Cuba. ${ }^{54}$ However, several Bakersfield and nearly all San Diego samples were found to fall within or above the range reported for the Baltic Sea (approx. 500-1000 copies/L). These two cities fell below the grand mean reported in the Almandres River in Cuba (approx. $10^{5}$ copies/L), but Los Angeles gene copy numbers were generally within its range of seasonal variation (approx. $1.3 \times 10^{3}$ to $3.2 \times 10^{5}$ ).

erm $\mathrm{F}$ copies per 16S-rRNA gene copies were found to occur in the literature in archived Scottish soils, ${ }^{7}$ with values far lower than the values frequently identified in this study. Other studies reporting erm $\mathrm{F}$ report nondetection of readings. ${ }^{26}$ erm $\mathrm{B}$ values 
have been reported in sediments in Cuba $\left(10^{3.7}-10^{5.4}\right.$ copies/ $\mathrm{g}){ }^{54}$ with these falling well above those identified in all California cities studied.

Intergene Observations. When analyzing drinking water samples, we observe that San Diego dominates in $b l a_{\mathrm{SHV}}$ presence across the cities studied, with the dominant city shifting to Los Angeles when analyzing the sull gene. This implies that it is ineffective to test for a small number of genes and assume results to be representative of ARG abundance in general. This is further observed when observing erm $\mathrm{F}$ and erm $\mathrm{B}$ soil data. Both genes provide resistance to erythromycin, acting as adenine N-6-methyltransferases and keeping erythromycin from inhibiting aminoacyl translocation. Despite having a similar function and conferring resistance to the same drug, city-to-city detection comparisons reveal that one gene is not necessarily a predictor for the other. This indicates that even genes closely related in function may not be able to behave as indicators for each other.

Statistical Analysis. Linear regression and correlation matrices between each gene and population, population density, and distance from the nearest feedlot operation revealed no direct relationships in either environmental compartment. ARGs across each environmental compartment could not be largely attributed to a particular factor. Instead, there exists a multifaceted set of influences that make ARG quantity prediction complex. In addition, statistical analysis between genes across environmental compartments additionally yielded no direct relationship between genes.

Environment and Health. A study of the resistome in human and environmental samples in low-income human habitats indicated ARG sharing between human, animal, and environmental microbial communities, reporting a positive correlation between the proportion of ARG contigs with a mobile genetic element (MGE) and the number of habitats encoding antibiotic resistance proteins, indicating a role for MGEs in environmental transfer. ${ }^{13}$

It is when analyzing $b a_{\mathrm{SHV}}$ in soils that we see the highest indicator of disparities in ARG quantities across cities. This is pertinent, as it has been suggested that $b a_{\mathrm{SHV}}$ be given a REScon 1 risk categorization, indicating that there exists published evidence that $b l a_{\mathrm{SHV}}$ poses a substantial risk for resistance dissemination and treatment failure. ${ }^{55}$ This is further alarming when considered in conjunction with the lack of current reporting for this gene, necessitating the re-evaluation of current approaches in reporting.

To conclude, this work amalgamates and extends observations reported globally on the quantity of ARGs in drinking water, soil, and air. Our results indicate that there exists a disparity in ARG quantities in the environment across four major cities within California. Additionally, this disparity is observed to be distinct within each environmental compartment as well as for each gene measured, highlighting the importance of testing a collection of ARGs to effectively identify environmental reservoirs and hinting at a complicated set of factors that dictate environmental ARG presence. These results were found to be consistent when gene copy numbers were analyzed by two different and widely used approaches, quantitative gene copy number per mass or volume of compartment as well as per 16S-rRNA gene copy. Future work should include follow-up studies to determine whether significant reservoirs for ARGs play the dual role of also being hotspots for HGT.
This article presents a monitoring approach that if standardized, prompts a more thorough global assessment and reporting of ARG quantities in environmental compartments. Moving forward, future regional assessments should focus on genes categorized as posing a higher risk for being acquired by and conferring resistance to human pathogens and should include data on co-contaminants, soil characterization, MGEs, and microbial community, where possible to create a larger database for statistical analysis. In doing so, further trends that might aid our understanding of antibiotic resistance proliferation and the dissemination of ARGs will be more easily identified.

\section{MATERIALS AND METHODS}

Site Selection. Los Angeles, San Diego, Fresno, and Bakersfield were chosen to provide a balance of land uses as well as a range of urbanization. For each city, three of the parks chosen were in the heart of the city, whereas the other three were positioned toward the outskirts. Proximity to major highways, where mixing of environmental influence and vehicular pollution was most likely, was avoided where possible. Priorities for inclusion in the study included accessible soil, presence of a water source, and access to a safe and stable airsampling location. A catalog of parks chosen for inclusion in this study along with population, population density, zip code, degree of urbanization, and distance from the nearest feedlot can be found in Table 1 of the Supporting Information.

Park urbanization was categorized as high, mid, or low on the basis of the number of roads and buildings located within a 500 $\mathrm{m}$ radius of the park. The parks whose $500 \mathrm{~m}$ radius included $\geq 75$ buildings and $\geq 15$ roads were categorized as highly urban, whereas the parks whose radius included $\leq 50$ buildings and $\leq 10$ roads were categorized as having low urbanization. Any park that fell between these designations was denoted as having midlevel urbanization. Buildings that fell on the circumference line were included in the count if over half of the building fell within the designated area of interest. This urbanization scheme is a modified urban intensity index as defined by the U.S. Environmental Protection Agency (EPA). A summary of urbanization categorization for each site can be found in Table 1.

Sample Collection. Soils. Three meter-squared plots were randomly selected at each park for soil sampling. Top soil was collected in $50 \mathrm{~mL}$ sterile falcon tubes by randomly selecting ten points in each plot and dipping the falcon tube to gather top soil $(0-2.5 \mathrm{~cm})$, yielding a composite sample representative of the meter-squared plot. This was repeated for the remaining two plots, yielding three falcon tubes that would be taken as representative of the site. Rocks and grass were avoided or removed using sterilized plastic scoops. Samples were kept on ice until transported to the laboratory, where tubes were stored at $4{ }^{\circ} \mathrm{C}$ prior to processing. For processing, soil tubes were extensively shaken to homogenize the ten points of collection and $0.25 \mathrm{~g}$ of each soil was weighed into individual $2 \mathrm{~mL}$ screw cap tubes preloaded with $1 \pm 0.05 \mathrm{~g}, 0.7 \mathrm{~mm}$ garnet beads ( $\mathrm{MO}$ BIO Laboratories, Inc., Carlsbad, CA) before being stored at $-20{ }^{\circ} \mathrm{C}$ to await DNA extraction. ${ }^{56}$ The remaining soil was used to conduct a moisture content, hydrolysis (soil composition), and loss on ignition analysis (see Table 2). All of the soil was processed within a week of sampling. Three samples were collected from each of the 24 parks, resulting in a total of $n=72$ soil samples. 
Tap Water. At each site, tap water was collected from either drinking fountains or exterior spigots. All water sources used were publicly accessible, and drinking fountains were prioritized whenever possible. Polypropylene plastic bottles used for sampling were washed and treated with $1.2 \mathrm{~N} \mathrm{HCl}$ overnight before being rinsed three times with milliQ water immediately prior to sample collection. A total of $10 \mathrm{~L}$ of sample was collected at each park just prior to returning to the laboratory. Samples took several minutes to obtain, and the resulting $10 \mathrm{~L}$ were a composite of water initially exiting each fountain (no flushing) as well as after several minutes of flushing. Samples were kept on ice for the duration of transport and stored at 4 ${ }^{\circ} \mathrm{C}$ until the time of processing. Processing consisted of vacuum-filtering $3 \mathrm{~L}$ of sample water through a $47 \mathrm{~mm}$ diameter, $0.4 \mu \mathrm{m}$ pore size polycarbonate filter (EMD Millipore, Billerica, MA). After filtration, filters were folded and placed into $2 \mathrm{~mL}$ screw cap tubes preloaded with $1 \pm 0.05$ $\mathrm{g}$ of $0.7 \mathrm{~mm}$ diameter garnet beads (MO BIO Laboratories, Inc., Carlsbad, CA), as required for DNA extraction. Tubes were subsequently stored at $-20{ }^{\circ} \mathrm{C}$, awaiting DNA extraction. All processing was performed in triplicate and all samples were processed within $48 \mathrm{~h}$ of collection.

Air. Air was collected in as close a proximity to parks as possible and not directly in parks due to considerations including park hours and duration of the sampling trip. Because of time constraints inherent to air sampling, not every park was sampled for air, yielding a smaller $n$ for air than that for soil and tap water. Air was collected at two sites per city, except for Fresno, where samples were collected from three sites. All sampling occurred in the months of January through March, 2015 to ensure that all cities were sampled within the same season, minimizing seasonal variation as a possible cause for city ARG disparities. ${ }^{57}$ In total, 24 samples were obtained for tap water and soil and 9 samples were obtained for air. Summary information for the sampling duration and sampling window can be found in Table S3.

Air sampling was conducted using three to five simultaneously operating personal pumps (SKC 224-PCXR4 Aircheck Sampler, SKC Inc. Eighty Four, PA). Operation was set to a flow rate of $2 \mathrm{~L} / \mathrm{min}$ for at least $4 \mathrm{~h}$, and air samples were obtained from a height of approximately $1 \mathrm{~m}$. Longer sampling times were preferable if possible and variances between sampling duration were corrected for during data analysis. The use of $7 \mathrm{~mm}$ diameter, $0.4 \mu \mathrm{m}$ pore size polycarbonate filters (EMD Millipore, Billerica, MA) and $45.72 \mathrm{~mm}, 1.6 \mu \mathrm{m}$ glass fiber filters (EMD Millipore, Billerica, MA) was interchangeable, with glass fiber filters manually cut in a sterile environment to a size of $7 \mathrm{~mm}$. A short preliminary experiment conducted prior to sampling concluded that both filter types yielded a comparable quantity of DNA for the same sampling duration upon extraction. Upon sampling completion, all filters were immediately folded and placed in $2 \mathrm{~mL}$ screw cap tubes preloaded with $1 \pm 0.05 \mathrm{~g}$ of $0.7 \mathrm{~mm}$ diameter garnet beads (MO BIO Laboratories, Inc., Carlsbad, CA) as specified for DNA extraction. Sample tubes were placed on ice and kept at 4 ${ }^{\circ} \mathrm{C}$ to the extent possible before transport to the laboratory, where they were stored at $-20{ }^{\circ} \mathrm{C}$ prior to DNA extraction.

DNA Extraction. All drinking water and soil DNA extractions were completed using the MoBio PowerFecal DNA Isolation Kit (MO BIO Laboratories, Inc., Carlsbad, CA) within 1 week of collection. Air samples were extracted within 3 months of collection. Extractions proceeded as per the manufacturer's guidelines except for the cell lysis step, where bead-beating for $2 \mathrm{~min}$ via a BioSpec MiniBeadbeater- 8 (BioSpec Products, Bartlesville, OK) was used in place of vortexing. An additional $2 \mathrm{~mL}$ screw cap tube preloaded with 1 $\pm 0.05 \mathrm{~g}$ of $0.7 \mathrm{~mm}$ diameter garnet beads ( $\mathrm{MO} \mathrm{BIO}$ Laboratories, Inc., Carlsbad, CA) and without sample (extraction blank) was included in every extraction to identify the contamination incurred during the extraction process, should it occur. Eluted DNA was aliquoted and stored at -20 ${ }^{\circ} \mathrm{C}$, awaiting qPCR analysis. The total DNA concentration was determined using UV absorption via a Nanodrop $2000 \mathrm{C}$ (Thermo Scientific, Waltham, MA), as were 260/280 absorbance ratios. Gene recovery for samples of similar soil composition extracted, as described in this study, was calculated via a matrix spike and found to be $83 \%$. For matrix spike methods, see Supporting Information.

qPCR. All samples were analyzed for ARG abundance of sull, $b l a_{\mathrm{SHV}}$, and the 16S-rRNA gene, (a total bacteria surrogate measure) via qPCR. Soil samples were additionally analyzed for ermB and ermF genes. All assays utilized SYBR Green Master Mix and entailed a $25 \mu \mathrm{L}$ of reaction volume consisting of 12.5 $\mu \mathrm{L}$ of $2 \mathrm{X}$ SYBR Green Master Mix (Life Technologies, Grand Island, NY), $1.25 \mu \mathrm{L}$ of each primer, forward and reverse primer, and at least $2 \mu \mathrm{L}$ of the template DNA, with moleculargrade water comprising any remaining reaction volume. Primers used were as developed and validated previously in the literature $\mathrm{24}^{24}$ and can be found in Table S4, along with primer concentrations. Each assay run included a 7-point standard curve positive control, all applicable extraction blanks, and a negative control of molecular-grade water, with each sample plated in triplicate. All assays were performed in 96-well reaction plates using StepOne Plus (Applied Biosystems). The temperature cycles used can be found in Table S3 and were as reported previously in literature. ${ }^{24,58}$

Both soil and water samples were diluted to a concentration of $0.25 \mathrm{ng} / \mu \mathrm{L}$ prior to $\mathrm{qPCR}$ to offset inhibition effects, as confirmed by well spike and inhibition dilution. Although the sul1 gene assay was found to amplify smoothly for a total mass of $0.5 \mathrm{ng} \mathrm{DNA}$, the $b \mathrm{a}_{\mathrm{SHV}}$, ermF, ermB, and 16S-rRNA gene assays were modified to contain $2.5 \mathrm{ng}$ to properly amplify. Template DNA and molecular-grade water volumes were varied as was necessary for each assay. Dilution factors were backcalculated during data analysis to reverse this effect and obtain per volume or per mass quantification. This dilution process was not found to be necessary for air samples. For well spike and inhibition dilution methods, see Supporting Information.

Target-containing DNA fragments to serve as positive controls were designed using Geneious coupled with NCBI database information and ordered through IDT Technologies. Known concentrations of the designed DNA fragment were run alongside environmental samples, yielding a seven-point standard curve and allowing for quantitation of gene copies. Melt curves were used to further verify correct target gene amplification.

Cataloging Globally Reported ARG Quantities. When assessing reported ARG quantities, only peer-reviewed articles were considered. Literature was confined to those reporting genes corresponding to the present study, where qPCR was used to determine ARG in environmental samples. Studies assessing gene quantities in subsets, that is, ARB that were cultured and subsequently analyzed via $\mathrm{qPCR}$, were excluded. Included studies reported values for gene count per volume or mass, or a ratio of gene of interest per 16S-rRNA gene. Values used for comparison to the present data set were estimated 
from plots where necessary, although directly reported values were prioritized when available. Values considered did not include quantities reported following an input of interest, that is, intentional antibiotic enrichment, reclaimed water use, metals enrichment, and so forth. It is important to note that due to limited reporting values presented here are compared to values across different years.

\section{ASSOCIATED CONTENT}

\section{S Supporting Information}

The Supporting Information is available free of charge on the ACS Publications website at DOI: 10.1021/acsomega.7b00118.

Detailed tables for study locations, soil characterization results, air sampling details, and $\mathrm{qPCR}$ primer sequences (PDF)

\section{AUTHOR INFORMATION}

\section{Corresponding Author}

*E-mail: jjay@seas.ucla.edu.

\section{ORCID}

Suzanne E. Paulson: 0000-0003-0855-7615

Yifang Zhu: 0000-0002-0591-3322

Jennifer A. Jay: 0000-0001-5417-1516

\section{Notes}

The authors declare no competing financial interest.

\section{ACKNOWLEDGMENTS}

We thank N. Garrison and C. Cordova for assistance in planning the study and the UCLA Institute of the Environment and Sustainability for supporting this work as a Senior Practicum Project. Funding was provided by the Natural Resources Defense Council and the UCLA Institute for the Environment and Sustainability. This material is based upon research performed in a collaboratory renovated by the National Science Foundation under Grant No. 0963183, which is an award funded under the American Recovery and Reinvestment Act of 2009 (ARRA).

\section{REFERENCES}

(1) O'Neill, J. Antimicrobial Resistance: Tackling A Crisis for the Health and Wealth of Nations, Review on Antimicrobial Resistance; Wellcome Trust and the HM Government: U.K., 2014; pp 1-16.

(2) O’Neill, J. Tackling Drug-Resistant Infections Globally: Final Report and Recommendations, Review on Antimicrobial Resistance; Wellcome Trust and the HM Government: U.K., 2016.

(3) Liu, Y.-Y.; Wang, Y.; Walsh, T. R.; Yi, L. X.; Zhang, R.; Spencer, J.; Doi, Y.; Tian, G.; Dong, B.; Huang, X.; et al. Emergence of plasmidmediated colistin resistance mechanism MCR-1 in animals and human beings in China: A microbiological and molecular biological study. Lancet Infect. Dis. 2016, 16, 161-168.

(4) Olaitan, A. O.; Thongmalayvong, B.; Akkhavong, K.; Somphavong, S.; Paboriboune, P.; Khounsy, S.; Morand, S.; Rolain, J.-M. Clonal transmission of a colistin-resistant Escherichia coli from a domesticated pig to a human in Laos. J. Antimicrob. Chemother. 2015, $1-2$.

(5) Davison, J. Genetic exchange between bacteria in the environment. Plasmid 1999, 42, 73-91.

(6) Baker-Austin, C.; Wright, M. S.; Stepanauskas, R.; McArthur, J. V. Co-selection of antibiotic and metal resistance. Trends Microbiol. 2006, 14, 176-182.

(7) Knapp, C. W.; McCluskey, S. M.; Singh, B. K.; Campbell, C. D.; Hudson, G.; Graham, D. W. Antibiotic resistance gene abundances correlate with metal and geochemical conditions in archived Scottish soils. PLoS One 2011, 6, No. e27300.

(8) Seiler, C.; Berendonk, T. U. Heavy metal driven co-selection of antibiotic resistance in soil and water bodies impacted by agriculture and aquaculture. Front. Microbiol. 2012, 3, No. 399.

(9) Pruden, A.; Pei, R.; Storteboom, H.; Carlson, K. H. Antibiotic resistance genes as emerging contaminants: Studies in northern Colorado. Environ. Sci. Technol. 2006, 40, 7445-7450.

(10) Pruden, A.; Arabi, M.; Storteboom, H. N. Correlation between upstream human activities and riverine antibiotic resistance genes. Environ. Sci. Technol. 2012, 46, 11541-11549.

(11) Schnoor, J. L. Re-emergence of emerging contaminants. Environ. Sci. Technol. 2014, 48, 11019-11020.

(12) Sanderson, H.; Fricker, C.; Brown, R. S.; Majury, A.; Liss, S. N. Antibiotic Resistance Genes as an Emerging Environmental Contaminant Haley. Environ. Rev. 2016, 24, 205-218.

(13) Pehrsson, E.; Tsukayama, P.; Patel, S.; Mejía-Bautista, M.; SosaSoto, G.; Navarrete, K. M.; Calderon, M.; Cabrera, L.; Hoyos-Arango, W.; Bertoli, M. T.; et al. Interconnected microbiomes and resistomes in low-income human habitats. Nature 2016, 61, 5985-5991.

(14) Finley, R. L.; Collignon, P.; Larsson, D. G. J.; Mcewen, S. A.; Li, X. Z.; Gaze, W. H.; Reid-Smith, R.; Timinouni, M.; Graham, D. W.; Topp, E. The scourge of antibiotic resistance: The important role of the environment. Clin. Infect. Dis. 2013, 57, 704-710.

(15) Wright, G. D. Antibiotic resistance in the environment: A link to the clinic? Curr. Opin. Microbiol. 2010, 13, 589-594.

(16) Auerbach, E. A.; Seyfried, E. E.; McMahon, K. D. Tetracycline resistance genes in activated sludge wastewater treatment plants. Water Res. 2007, 41, 1143-1151.

(17) Munir, M.; Wong, K.; Xagoraraki, I. Release of antibiotic resistant bacteria and genes in the effluent and biosolids of five wastewater utilities in Michigan. Water Res. 2011, 45, 681-693.

(18) Rizzo, L.; Manaia, C.; Merlin, C.; Schwartz, T.; Dagot, C.; Ploy, M. C.; Michael, I.; Fatta-Kassinos, D. Urban wastewater treatment plants as hotspots for antibiotic resistant bacteria and genes spread into the environment: A review. Sci. Total Environ. 2013, 447, 345360.

(19) Li, J.; Wang, T.; Shao, B.; Shen, J.; Wang, S.; Wu, Y. Plasmidmediated quinolone resistance genes and antibiotic residues in wastewater and soil adjacent to swine feedlots: Potential transfer to agricultural lands. Environ. Health Perspect. 2012, 120, 1144-1149.

(20) Koike, S.; Krapac, I. G.; Oliver, H. D.; Yannarell, A. C.; CheeSanford, J. C.; Aminov, R. I.; Mackie, R. I. Monitoring and source tracking of tetracycline resistance genes in lagoons and groundwater adjacent to swine production facilities over a 3-year period. Appl. Environ. Microbiol. 2007, 73, 4813-4823.

(21) Heuer, H.; Solehati, Q.; Zimmerling, U.; Kleineidam, K.; Schloter, M.; Müller, T.; Focks, A.; Thiele-Bruhn, S.; Smalla, K. Accumulation of sulfonamide resistance genes in arable soils due to repeated application of manure containing sulfadiazine. Appl. Environ. Microbiol. 2011, 77, 2527-2530.

(22) Rodriguez-Mozaz, S.; Chamorro, S.; Marti, E.; Huerta, B.; Gros, M.; Sànchez-Melsió, A.; Borrego, C. M.; Barceló, D.; Balcázar, J. L. Occurrence of antibiotics and antibiotic resistance genes in hospital and urban wastewaters and their impact on the receiving river. Water Res. 2015, 69, 234-242.

(23) Walia, S.; Murleedharn, C.; Band, J.; Kanwar, M.; Kumar, A. Quantitation of antibiotic resistance genes pollution in hospital waste water effluent and Urban Clinton River Water, Michigan, USA. Curr. Med. Res. Pract. 2016, 6, 149-151.

(24) Knapp, C. W.; Dolfing, J.; Ehlert, P. A. I.; Graham, D. W. Evidence of increasing antibiotic resistance gene abundances in archived soils since 1940. Environ. Sci. Technol. 2010, 44, 580-587.

(25) Chee-Sanford, J. C.; Mackie, R. I.; Koike, S.; Krapac, I. G.; Lin, Y.-F.; Yannarell, A. C.; Maxwell, S.; Aminov, R. I. Fate and Transport of Antibiotic Residues and Antibiotic Resistance Genes following Land Application of Manure Waste. J. Environ. Qual. 2009, 38, 1086.

(26) Fahrenfeld, N.; Knowlton, K.; Krometis, L. A.; Hession, W. C.; Xia, K.; Lipscomb, E.; Libuit, K.; Green, B. L.; Pruden, A. Effect of 
manure application on abundance of antibiotic resistance genes and their attenuation rates in soil: Field-scale mass balance approach. Environ. Sci. Technol. 2014, 48, 2643-2650.

(27) Binh, C. T. T.; Heuer, H.; Kaupenjohann, M.; Smalla, K. Diverse aadA gene cassettes on class 1 integrons introduced into soil via spread manure. Res. Microbiol. 2009, 160, 427-433.

(28) Dalkmann, P.; Broszat, M.; Siebe, C.; Willaschek, E.; Sakinc, T.; Huebner, J.; Amelung, W.; Grohmann, E.; Siemens, J. Accumulation of pharmaceuticals, enterococcus, and resistance genes in soils irrigated with wastewater for zero to 100 years in central Mexico. PLoS One 2012, 7, No. e45397.

(29) Chen, C.; Li, J.; Chen, P.; Ding, R.; Zhang, P.; Li, X. Occurrence of antibiotics and antibiotic resistances in soils from wastewater irrigation areas in Beijing and Tianjin, China. Environ. Pollut. 2014, 193, 94-101.

(30) Han, X. M.; Hu, H. W.; Shi, X. Z.; Wang, J. T.; Han, L. L.; Chen, D.; He, J. Z. Impacts of reclaimed water irrigation on soil antibiotic resistome in urban parks of Victoria, Australia. Environ. Pollut. 2016, $211,48-57$.

(31) Pruden, A.; Pei, R.; Storteboom, H.; Carlson, K. H. Antibiotic resistance genes as emerging contaminants: studies in northern Colorado. Environ. Sci. Technol. 2006, 40, 7445-7450.

(32) Luo, Y.; Mao, D.; Rysz, M.; Zhou, Q.; Zhang, H.; Xu, L.; Alvarez, P. J. J. Trends in antibiotic resistance genes occurrence in the Haihe River, China. Environ. Sci. Technol. 2010, 44, 7220-7225.

(33) Niu, Z.-G.; Zhang, K.; Zhang, Y. Occurrence and distribution of antibiotic resistance genes in the coastal area of the Bohai Bay, China. Mar. Pollut. Bull. 2016, 107, 245-250.

(34) Dodd, M. C. Potential impacts of disinfection processes on elimination and deactivation of antibiotic resistance genes during water and wastewater treatment. J. Environ. Monit. 2012, 14, 1754-1771.

(35) Gomez-Alvarez, V.; Revetta, R. P.; Domingo, J. W. S. Metagenomic analyses of drinking water receiving different disinfection treatments. Appl. Environ. Microbiol. 2012, 78, 6095-6102.

(36) Xu, L.; Ouyang, W.; Qian, Y.; Su, C.; Su, J.; Chen, H. Highthroughput profiling of antibiotic resistance genes in drinking water treatment plants and distribution systems. Environ. Pollut. 2016, 213, $119-126$.

(37) Khan, S.; Knapp, C. W.; Beattie, T. K. Antibiotic Resistant Bacteria Found in Municipal Drinking Water. Environ. Process. 2016, 541-552.

(38) Brooks, J. P.; McLaughlin, M. R.; Scheffler, B.; Miles, D. M. Microbial and antibiotic resistant constituents associated with biological aerosols and poultry litter within a commercial poultry house. Sci. Total Environ. 2010, 408, 4770-4777.

(39) Chapin, A.; Rule, A.; Gibson, K.; Buckley, T.; Schwab, K. Airborne multidrug-resistant bacteria isolated from a concentrated swine feeding operation. Environ. Health Perspect. 2005, 113, 137-142.

(40) Gibbs, S. G.; Green, C. F.; Tarwater, P. M.; Mota, L. C.; Mena, K. D.; Scarpino, P. V. Isolation of antibiotic-resistant bacteria from the air plume downwind of a swine confined or concentrated animal feeding operation. Environ. Health Perspect. 2006, 114, 1032-1037.

(41) McEachran, A. D.; Blackwell, B. R.; Hanson, J. D.; Wooten, K. J.; Mayer, G. D.; Cox, S. B.; Smith, P. N. Antibiotics, bacteria, and antibiotic resistance genes: Aerial transport from cattle feed yards via particulate matter. Environ. Health Perspect. 2015, 123, 337-343.

(42) Ling, A. L.; Pace, N. R.; Hernandez, M. T.; Lapara, T. M. Tetracycline resistance and class 1 integron genes associated with indoor and outdoor aerosols. Environ. Sci. Technol. 2013, 47, 40464052.

(43) Sanchez, H. M.; Echeverria, C.; Thulsiraj, V.; Zimmer-Faust, A.; Flores, A.; Laitz, M.; Healy, G.; Mahendra, S.; Paulson, S. E.; Zhu, Y.; et al. Antibiotic Resistance in Airborne Bacteria Near Conventional and Organic Beef Cattle Farms in California, USA. Water, Air, Soil Pollut. 2016, 227, No. 280.

(44) Nardelli, M.; Scalzo, P. M.; Ramirez, M. S.; Quiroga, M. P.; Cassini, M. H.; Centron, D. Class 1 integrons in environments with different degrees of urbanization. PLoS One 2012, 7, No. e39223.
(45) Enne, V. I.; Livermore, D. M.; Stephens, P.; Hall, L. M. C. Persistence of sulphonamide resistance in Escherichia coli in the UK despite national prescribing restriction. Lancet 2001, 357, 1325-1328.

(46) Hall, R. M.; Collis, C. M. Antibiotic resistance in gram-negative bacteria: the role of gene cassettes and integrons. Drug Resist. Updates 1998, 1, 109-119.

(47) Berendonk, T. U.; Manaia, C. M.; Merlin, C.; Fatta-Kassinos, D.; Cytryn, E.; Walsh, F.; Bürgmann, H.; Sørum, H.; Norström, M.; Pons, M.-N.; et al. Tackling antibiotic resistance: the environmental framework. Nat. Rev. Microbiol. 2015, 13, 310-317.

(48) Czekalski, N.; Gascón Díez, E.; Burgmann, H. Wastewater as a point source of antibiotic-resistance genes in the sediment of a freshwater lake. ISME J. 2014, 8, 1381-1390.

(49) Suzuki, S.; Ogo, M.; Miller, T. W.; Shimizu, A.; Takada, H.; Siringan, M. A. T. Who possesses drug resistance genes in the aquatic environment?: Sulfamethoxazole (SMX) resistance genes among the bacterial community in water environment of Metro-Manila, Philippines. Front. Microbiol. 2013, 4, No. 102.

(50) Suzuki, S.; Ogo, M.; Koike, T.; Takada, H.; Newman, B. Sulfonamide and tetracycline resistance genes in total- and culturablebacterial assemblages in south african aquatic environments. Front. Microbiol. 2015, 6, No. 796.

(51) Tiirik, K.; Nõlvak, H.; Oopkaup, K.; Truu, M.; Preem, J. K.; Heinaru, A.; Truu, J. Characterization of the bacterioplankton community and its antibiotic resistance genes in the Baltic Sea. Biotechnol. Appl. Biochem. 2014, 61, 23-32.

(52) Czekalski, N.; Sigdel, R.; Birtel, J.; Matthews, B.; Burgmann, H. Does human activity impact the natural antibiotic resistance background? Abundance of antibiotic resistance genes in 21 Swiss lakes. Environ. Int. 2015, 81, 45-55.

(53) Guo, X.; Li, J.; Yang, F.; Yang, J.; Yin, D. Prevalence of sulfonamide and tetracycline resistance genes in drinking water treatment plants in the Yangtze River Delta, China. Sci. Total Environ. 2014, 493, 626-631.

(54) Knapp, C. W.; Lima, L.; Olivares-Rieumont, S.; Bowen, E.; Werner, D.; Graham, D. W. Seasonal variations in antibiotic resistance gene transport in the Almendares River, Havana, Cuba. Front. Microbiol. 2012, 3, No. 396.

(55) Martinez, J. L.; Coque, T. M.; Baquero, F. What is a resistance gene? Ranking risk in resistomes. Nat. Rev. Microbiol. 2015, 13, 116123.

(56) Simmons, K.; Deatric, J.; Levis, B. Soil Sampling: SESD Operating Procedure; US EPA, 2014; pp 1-24.

(57) Ravva, S. V.; Hernlem, B. J.; Sarreal, C. Z.; Mandrell, R. E. Bacterial communities in urban aerosols collected with wetted-wall cyclonic samplers and seasonal fluctuations of live and culturable airborne bacteria. J. Environ. Monit. 2012, 14, 473.

(58) Ji, X.; Shen, Q.; Liu, F.; Ma, J.; Xu, G.; Wang, Y.; Wu, M. Antibiotic resistance gene abundances associated with antibiotics and heavy metals in animal manures and agricultural soils adjacent to feedlots in Shanghai; China. J. Hazard. Mater. 2012, 235-236, 178185 . 